\section{Vegetative Propagation of Mountain Fly Honeysuckle (Lonicera villosa) by Overhead Mist and Subirrigation}

\author{
Darren J. Hayes ${ }^{1}$ and Bryan J. Peterson \\ School of Food and Agriculture, University of Maine, 5722 Deering Hall, \\ Orono, ME 04469
}

Additional index words. adventitious root formation, honeyberry, K-IBA, landscape performance, Lonicera caerulea, WinRHIZO

\begin{abstract}
We assessed adventitious root formation on stem cuttings of mountain fly honeysuckle [Lonicera villosa (Michx.) Schult.] in separate experiments using overhead mist and subirrigation systems. The concentration of applied potassium salt of indole-3butyric acid (K-IBA) and the proportions of coarse perlite and milled peatmoss in the propagation medium were varied within both systems. Across treatments, $98 \%$ of cuttings in the overhead mist system and $85 \%$ of cuttings in the subirrigation system produced roots. In the overhead mist system, root volume, root dry weight, and number of root tips were greatest among cuttings treated with 4000 to $12,000 \mathrm{mg} \cdot \mathrm{L}^{-1} \mathrm{~K}-\mathrm{IBA}$ and stuck into $100 \%$ perlite. In the subirrigation system, root dry weight was not significantly affected by K-IBA concentration, but the greatest root volume and number of root tips were produced by cuttings treated with 8000 or $12,000 \mathrm{mg} \cdot \mathrm{L}^{-1} \mathrm{~K}-\mathrm{IBA}$ and stuck into $100 \%$ perlite. Despite the natural affinity of mountain fly honeysuckle for moist, organic soils, all of the 18 rooted cuttings we planted in a landscape trial survived and grew appreciably with minimal care over 2 years in a mineral field soil. We conclude that cuttings of mountain fly honeysuckle can be propagated readily by overhead mist or subirrigation, that root system quality is improved substantially by increasing K-IBA concentration and using coarse perlite without peatmoss, and that mountain fly honeysuckle can be grown in typical horticultural landscapes.
\end{abstract}

Eurasian honeysuckle species such as Lonicera maackii (Rupr.) Herder and Lonicera tatarica L. have a long history as valued and widely planted components of both urban and rural landscapes, prized for their sweetly scented flowers, persistent and colorful fruit, and wide tolerance of climactic conditions since their introduction from Asia to the western hemisphere during the late 1800 s to early 1900 s (Bailey, 1919; Luken and Thieret, 1996). However, the tendency for Eurasian honeysuckles to escape cultivation and cause

Received for publication 24 Sept. 2018. Accepted for publication 19 Dec. 2018.

Maine Agriculture and Forestry Experiment Station publication no. 3643. This project was supported by the U.S. Department of Agriculture National Institute of Food and Agriculture Hatch Project \#ME021614 through the Maine Agricultural \& Forest Experiment Station, and by an Agricultural Research Service Cooperative Agreement for Project 8020-21000-147-06S.

We thank Bill Patterson, Nancy Sferra, The Nature Conservancy in Maine, Glenn Dixon, Bradly Libby, Greg Melcher, and Melissa Smith for helpful assistance.

Any opinions, findings, conclusions, or recommendations expressed in this publication are those of the authors and do not necessarily reflect the view of the National Institute of Food and Agriculture (NIFA) or the U.S. Department of Agriculture (USDA).

${ }^{1}$ Corresponding author. E-mail: darren.hayes@ maine.ed0075. ecosystem changes in North America was first documented in the mid 1900s (Luken and Thieret, 1996), and public perception of these taxa has shifted to the point that they are being removed from nursery inventories and even banned in some parts of the United States (U.S. Department of Agriculture Natural Resources Conservation Service, 2018a). Given the long history of consumer demand for Lonicera spp. from Eurasia, the identification and propagation of native alternatives for the North American horticulture trade seems prudent.

Mountain fly honeysuckle [Lonicera villosa (Michx.) Schult.] is an attractive shrub that may have value as a small native alternative to cultivars of blue honeysuckle (Lonicera caerulea L.) that recently have been developed from Eurasian germplasm (Gerbrandt et al., 2017). Because of its similarities to Eurasian members of the species complex, mountain fly honeysuckle is also commonly considered to be a subspecies or variety of a broadly distributed $L$. caerulea, although it differs in morphology from its Eurasian congeners (Fernald, 1925) and the taxonomy is not settled (Peterson et al., 2018). Mountain fly honeysuckle is indigenous to much of Canada, with a patchy range that extends into the northeastern and Great Lakes regions of the United States, although it is presumed extirpated in Ohio and is endangered in Pennsylvania (U.S. Department of Agriculture Natural Resources Conservation Service, 2018a).
Mountain fly honeysuckle is typically found in bogs and fens, in addition to mesic forests, as a small shrub that occasionally reaches 3 to $4 \mathrm{ft}$ in height. Its coriaceous and rugose leaves are dark green and sparsely to densely pubescent with a pale abaxial surface (Fernald, 1925). Mountain fly honeysuckle displays reddish brown to coppery stems, and bark that exfoliates into persistent strips as the stems age. Plants produce small, paired yellow flowers in early spring, and ediblebut-tart oblong blue fruit that ripens in early summer. The fruit is also attractive to birds, but seems to be produced in low abundance within natural habitats.

Propagation of native plants is a necessary first step toward developing them for horticultural or conservation purposes. Stem cuttings often are rooted to produce plants both for sale in the horticulture industry (Hartmann et al., 2011) and for restoration of natural ecosystems (Dreesen et al., 2002). Cutting phenology, method of irrigation (Svenson, 2018), medium composition (AlSalem and Karam, 2001), and plant growth regulator treatments all influence rooting success, and optimal treatments are often taxon specific (Dirr and Heuser, 2006; Hartmann et al., 2011). Successful introduction of mountain fly honeysuckle to the horticulture trade will depend, moreover, on its capacity to establish and thrive in developed landscapes that may be dissimilar from native environments.

We assessed root development on stem cuttings of mountain fly honeysuckle that were treated with solutions varying in concentration of K-IBA and inserted into propagation media varying in their proportions of coarse perlite and milled peatmoss. The effects of these treatments were evaluated in both overhead mist and subirrigation systems, with the former representing a reliable industry standard and the latter representing a low-cost and low-tech alternative that may produce comparable, or even superior, results for some taxa (Svenson, 2018; Zhang and Graves, 1995). We also planted rooted cuttings of mountain fly honeysuckle into a garden plot and evaluated their survival and growth over 2 years.

\section{Materials and Methods}

\section{Propagation experiments}

Plant materials and handling. On 28 June 2017, we collected 384 softwood terminal stem cuttings from 17 healthy plants of mountain fly honeysuckle indigenous to Lubec, ME (lat. $44^{\circ} 48^{\prime} 03.4^{\prime \prime} \mathrm{N}$, long. $67^{\circ} 07^{\prime} 35.4^{\prime \prime} \mathrm{W}$ ). Sampled plants were a minimum of $1 \mathrm{~m}$ apart along a roadside and were presumed to be genetically distinct. Cuttings, which had two to three nodes and averaged $6.3 \mathrm{~cm}$, were placed in plastic bags, misted, transported to a floral cooler (SRC Refrigeration, Sterling Heights, MI) maintained at $5.5^{\circ} \mathrm{C}$, and processed the day after collection. Leaves were removed from the basal node of each cutting, and stems were wounded lightly by scraping the basal 1 to $2 \mathrm{~cm}$ of the stem on one side with a razor blade, a procedure 
observed to increase rooting quality in a preliminary study. Basal ends of cuttings were dipped for $5 \mathrm{~s}$ into water or into solutions of 4000,8000 , or $12,000 \mathrm{mg} \cdot \mathrm{L}^{-1} \mathrm{~K}-\mathrm{IBA}$ dissolved in water. Cuttings were subsequently stuck into 50-cell 1020 propagation sheets (Dillen-ITML, Middlefield, $\mathrm{OH}$ ) filled with supercoarse horticultural perlite (Whittemore Co., Inc., Lawrence, MA) and professional-grade milled peatmoss (Sungro, Agawam, MA). The percentage of perlite was $50 \%, 75 \%$, or $100 \%$ by volume, with the remaining volume occupied by peatmoss. This resulted in a $4 \times 3$ full factorial design with 12 treatment combinations. Cuttings were watered in and were then placed in one of two propagation systems: overhead mist or subirrigation. Space limitations precluded replicate installations on the systems level, so overhead mist and subirrigation were assessed in separate experiments.

Overhead mist study design. Cuttings in the experiment irrigated via overhead mist were assigned to cells of five 50-cell propagation sheets in a completely randomized design, with 20 replications per factorial treatment combination $(\mathrm{N}=240)$. The propagation sheets were inserted into meshbottomed 1020 trays that were placed edge-to-edge on the mist bench to create a continuous $10-\times 24$-cell propagation area. Cuttings received $8 \mathrm{~s}$ of mist every $10 \mathrm{~m}$ for the duration of the experiment.

Subirrigation study design. In the experiment irrigated via subirrigation, 50-cell propagation flats were cut to create 12-cell units (three cells by four cells), each of which was placed in its own subirrigation tray consisting of a $20-\times 20-\mathrm{cm}$ disposable aluminum baking pan lined with clear plastic wrap. Substrate and K-IBA treatment combinations were assigned randomly to each cell, with one replicate of each combination per subirrigation tray. The experiment was a randomized complete block design, with 12 trays serving as blocks, each holding one replicate per factorial combination $(\mathrm{n}=12$, $\mathrm{N}=144$ ). Trays remained unirrigated for $12 \mathrm{~h}$ to reduce the potential for leaching of applied K-IBA, after which they were filled with tap water to a depth of $3 \mathrm{~cm}$ and refilled to the same depth daily. Although the potential existed for hormone leaching through the subirrigation water to confound the effects of prescribed treatments, the influence of auxin concentration in the subirrigation experiment was not ambiguous and paralleled the results in the overhead mist experiment.

Environmental conditions. The two experiments were conducted on a single bench under $25 \%$ mylar shadecloth in the glass-glazed Roger Clapp Greenhouses at the University of Maine, Orono, with natural photoperiods. Temperature on the bench was logged using a Watchdog 1450 micro station with radiation shield (Spectrum Technologies, Aurora, IL) located under the shadecloth, near the height of the cuttings in the subirrigation experiment. The temperature averaged $25.4{ }^{\circ} \mathrm{C}$ for the experimental period, with a maximum instantaneous temperature of $38.8^{\circ} \mathrm{C}$. Photosynthetically active radiation $(P A R)$ under the shadecloth was measured once every 10 min using a quantum light sensor attached to the same data logger, and daily light integral (DLI) was calculated from these data. The average DLI was $7.36 \mathrm{~mol} \cdot \mathrm{m}^{-2} \cdot \mathrm{d}^{-1}$, with a maximum instantaneous $P A R$ reading of $667 \mu \mathrm{mol} \cdot \mathrm{m}^{-2} \cdot \mathrm{s}^{-1}$. Substrate porosities were characterized by filling three 1020 flats with each medium, gently firming by hand to approximate settling over time, wetting media thoroughly under mist for $48 \mathrm{~h}$, weighing flats, sealing holes in flats, adding water to fill the remaining pore space and weighing again, and then drying media for $7 \mathrm{~d}$ in a room maintained at $\approx 68{ }^{\circ} \mathrm{C}$ and weighing again. Average aeration porosities were $28.5 \%, 24.4 \%$, and $21.6 \%$, and average water-holding capacities were $44.5 \%, 48.1 \%$, and $52.5 \%$ for media comprising $100 \%, 75 \%$, and $50 \%$ perlite, respectively.

Data collection and analysis. Cuttings from the overhead mist experiment were harvested from 8 Aug. to 14 Aug. 2017, whereas cuttings from the subirrigation experiment were harvested from 15 Aug. to 20 Aug. In each propagation experiment, propagation success and root system quality were assessed via the same protocol. First, cuttings were uprooted and rinsed gently to remove substrate. Each cutting was rated on success of propagation in a binary fashion, with a score of 0 assigned to cuttings that died or failed to root, and a score of 1 assigned to cuttings that both survived and formed at least one adventitious root exceeding $1 \mathrm{~cm}$ in length. Roots were trimmed from each cutting using a scalpel and arranged on an Epson Expression 1680 flatbed scanner with transparency unit (Epson, Suwa, Nagano Prefecture, Japan). Roots were arranged to minimize overlap and crossing, and then were scanned and analyzed using WinRHIZO software version 2003b, which has been demonstrated to provide accurate measurements of total root volume and total number of root tips per cutting (Bouma et al., 2000). Roots were then dried to constant weight in open paper bags in a hot drying room maintained at $\approx 68{ }^{\circ} \mathrm{C}$ and weighed to determine root dry weights.

Data analysis was conducted using the statistical software R version 3.3.2 (R Core Team, 2016). Propagation success was analyzed via logistic regression, with overall effects of treatments on propagation success analyzed by the Wald test conducted using the aod version 1.1-32 (Lesnoff and Lancelot, 2012) package for R. Logistic regression analyzes the influence of independent variables on the probability of a binary dependent outcome (Vittinghoff et al., 2011). Least square difference tests were conducted using the agricolae version 1.2-4 (de Mendiburu, 2016) package for $R$, following detection of significant treatment effects by analysis of variance at an $\alpha$ value of 0.05 . Factorial interaction effects were not significant for any response variable, and interaction terms were subsequently omitted from statistical tests. Within the collection period from each system, the dates at which cuttings were processed explained no variation in rooting parameters when assessed by linear regression, indicating that roots had ceased growth before harvest. For cuttings rooted in overhead mist, square root transformations were performed on root volume, root dry weight, and root tip counts to improve normality. For cuttings rooted by subirrigation, a cube root transformation was performed on the root dry weights, and a square root transformation was performed on the root tip counts.

\section{Field trial}

Plant materials and handling. Eighteen plants of mountain fly honeysuckle were transplanted into a garden plot in Plymouth, ME, to assess plant survival and performance in a mineral field soil. Plants were propagated from semihardwood cuttings collected in July 2015 from indigenous plants within the Maine counties of Aroostook (lat. 45 $57^{\prime} 21.9^{\prime \prime} \mathrm{N}$, long. $68^{\circ} 21^{\prime} 53.5^{\prime \prime} \mathrm{W}$ ), Washington (lat. $44^{\circ} 48^{\prime} 03.4^{\prime \prime} \mathrm{N}$, long. $67^{\circ} 07^{\prime} 35.4^{\prime \prime W}$ ), and Kennebec (lat. $44^{\circ} 32^{\prime} 43.5^{\prime \prime} \mathrm{N}$, long. $\left.69^{\circ} 33^{\prime} 04.8^{\prime \prime} \mathrm{W}\right)$. Cuttings were treated with $4000 \mathrm{mg} / \mathrm{L} \mathrm{K}-\mathrm{IBA}$ and rooted under intermittent mist in $510-\mathrm{mL}$ vacuum pots $(8.9 \times 8.9 \mathrm{~cm}$; Dillen-ITML, Middlefield, $\mathrm{OH})$ filled with 1:1 peat:perlite (by volume). Rooted cuttings were overwintered in their containers from Nov. 2015 to Apr. 2016 in a cold room maintained at $4{ }^{\circ} \mathrm{C}$, transferred to an outdoor container nursery block, irrigated as needed, and fertilized with $1.5 \mathrm{~g}$ controlled-release fertilizer (Osmocote Pro 17N-2.2P-9.1K; Everris, Dublin, $\mathrm{OH})$ per container in May 2016.

Plants were transplanted into the trial plot in Plymouth, ME, on 20 Aug. 2016. The trial plot was characterized by well-drained fine sandy loam of the Peru-Tunbridge association (U.S. Department of Agriculture Natural Resources Conservation Service, $2018 \mathrm{~b})$. The soil texture measured $47 \%$ sand, $49 \%$ silt, and $4 \%$ clay using the sedimentation method for soil particle size analyses conducted over a 48 -h period on an aggregate soil sample. Soil pH measured 5.6 in a 1:2 soil:water extraction assessed with a handheld $\mathrm{pH} /$ electrical conductivity/total dissolved solids/temperature meter (Hanna Instruments, Woonsocket, RI). The plot was partially enclosed by a canopy of green ash (Fraxinus pennsylvanica Marsh.) estimated at $20 \%$ cover, which shaded the plot until late morning, after which the plot received full sun for the remainder of the day. A rototiller was used to prepare the bed and control weeds, and plants of mountain fly honeysuckle were transplanted into the plot with $1-\mathrm{m}$ spacing between individuals. Plants were irrigated as needed throughout Summer and Fall 2016, after which supplemental irrigation was ended. No mulches or fertilizers were applied to the plots during the study period.

Field trial data collection and analysis. In the field trial, plant survival, number of primary stems, primary stem caliper, seasonal stem growth, plant height, and canopy spread were measured on 6 July 2018, after the period of active primary growth in the 


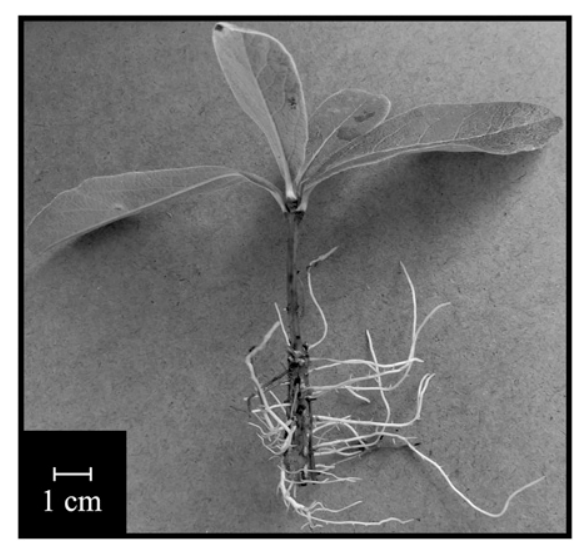

Fig. 1. Rooted cutting of mountain fly honeysuckle after 6 weeks in overhead mist.

spring, which was confirmed by extensive stem lignification and terminal bud set. Because mountain fly honeysuckle tends to form a multistem shrub, primary stems in this instance were defined as stems arising from the first $5 \mathrm{~cm}$ of aboveground growth, and primary stem caliper was measured $1 \mathrm{~cm}$ above the soil line on the largest stem emerging directly from the soil. Descriptive statistics (mean and SD from the mean) were calculated for each measured parameter.

\section{Results}

Propagation experiments. Treatments did not have a significant effect on the probability of root formation in either experimental system. Propagation success of cuttings that received overhead mist was $98 \%(\mathrm{SD}=14)$, regardless of treatment combination. Propagation success was $85 \%(\mathrm{sD}=35)$ across treatments in the subirrigation system. An example of a typical rooted cutting of mountain fly honeysuckle is presented in Fig. 1.

Among cuttings rooted in the overhead mist system, those treated with K-IBA exhibited two times greater root volume, root dry weight, and number of root tips than the untreated controls (Table 1). There were no significant differences in these parameters among cuttings that received K-IBA. Cuttings in media consisting of $100 \%$ perlite had greater root volume and root dry weight than those in media containing peatmoss (Table 1; Fig. 2). Number of root tips did not differ significantly with the percentage of perlite in the rooting medium.

Among cuttings rooted in subirrigation trays, root volume and number of root tips differed significantly with K-IBA application (Table 2). The two highest concentrations of K-IBA yielded cuttings with the greatest root volume and number of root tips, with nearly a $50 \%$ increase over controls that did not receive K-IBA. Root volume, root dry weight, and number of root tips also increased with the percentage of perlite in the medium. Cuttings in $100 \%$ perlite had 2.8 times the root volume, 4.2 times the root dry

Table 1. Influence of potassium salt of indole-3-butyric acid (K-IBA) application (top) or perlite content of the rooting medium (bottom) on root volume, root dry weight, and number of root tips on mountain fly honeysuckle stem cuttings rooted in an overhead mist system.

\begin{tabular}{lccc}
\hline & Root volume $\left(\mathrm{mm}^{3}\right)^{\mathrm{z}}$ & Root dry wt $(\mathrm{mg})^{\mathrm{z}}$ & No. of root tips $^{\mathrm{z}}$ \\
\hline K-IBA $\left(\mathrm{mg} \cdot \mathrm{L}^{-1}\right)$ & $90 \mathrm{~b}^{\mathrm{y}}$ & $28 \mathrm{~b}$ & $220 \mathrm{~b}$ \\
0 & $180 \mathrm{a}$ & $54 \mathrm{a}$ & $414 \mathrm{a}$ \\
4,000 & $190 \mathrm{a}$ & $58 \mathrm{a}$ & $468 \mathrm{a}$ \\
8,000 & $190 \mathrm{a}$ & $55 \mathrm{a}$ & $491 \mathrm{a}$ \\
12,000 & & & 381 \\
Perlite $(\%)^{\mathrm{x}}$ & $129 \mathrm{~b}$ & $40 \mathrm{~b}$ & 378 \\
50 & $128 \mathrm{~b}$ & $39 \mathrm{~b}$ & 407 \\
75 & $229 \mathrm{a}$ & $65 \mathrm{a}$ & \\
100 & & & \\
\hline
\end{tabular}

${ }^{\mathrm{z}}$ Data were square root-transformed for statistical analysis. Treatment means were back-transformed for reporting.

${ }^{\mathrm{y}}$ Means within each column and factor followed by the same letter are not significantly different at $\alpha=$ 0.05 . Columns without letters did not have significant analysis of variance treatment effects at $P \leq 0.05$. ${ }^{\mathrm{x}}$ Peatmoss occupied the remaining volume of each medium.

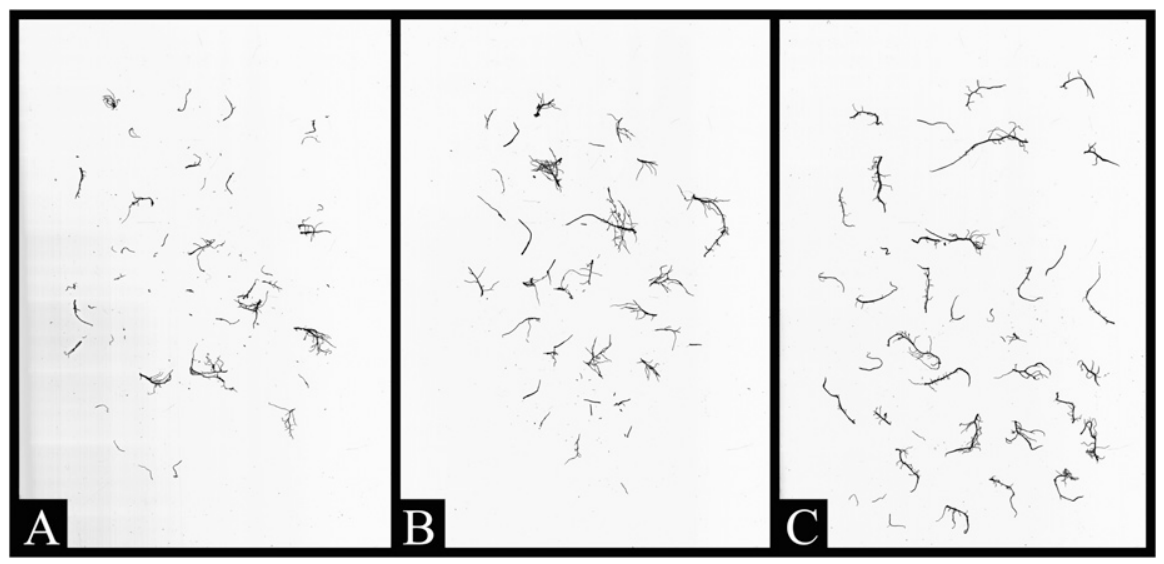

Fig. 2. Digital scans of the median root system (by dry weight) among cuttings propagated by overhead mist in each of three substrates: (A) $50 \%$ perlite and $50 \%$ peatmoss, (B) $75 \%$ perlite and $25 \%$ peatmoss, and (C) $100 \%$ perlite. Each digital scan represents an area of $21.5 \times 30 \mathrm{~cm}$.

Table 2. Influence of potassium salt of indole-3-butyric acid (K-IBA) application (top) or perlite content of the rooting medium (bottom) on root volume, root dry weight, and number of root tips on mountain fly honeysuckle stem cuttings rooted in a subirrigation system.

\begin{tabular}{lccc}
\hline & Root volume $\left(\mathrm{mm}^{3}\right)$ & Root dry wt $(\mathrm{mg})^{\mathrm{z}}$ & No. of root tips $^{\mathrm{y}}$ \\
\hline K-IBA (mg.L r $\left.^{-1}\right)$ & $249 \mathrm{~b}^{\mathrm{x}}$ & 54 & $466 \mathrm{~b}$ \\
0 & $284 \mathrm{ab}$ & 67 & $562 \mathrm{ab}$ \\
4,000 & $335 \mathrm{a}$ & 85 & $635 \mathrm{a}$ \\
8,000 & $355 \mathrm{a}$ & 78 & $689 \mathrm{a}$ \\
12,000 & & & $340 \mathrm{c}$ \\
Perlite $(\%)^{\mathrm{w}}$ & $166 \mathrm{c}$ & $33 \mathrm{c}$ & $515 \mathrm{~b}$ \\
50 & $258 \mathrm{~b}$ & $55 \mathrm{~b}$ & $900 \mathrm{a}$ \\
75 & $460 \mathrm{a}$ & $137 \mathrm{a}$ & \\
100 & & & \\
\hline
\end{tabular}

${ }_{\mathrm{z}}$ Data were cube root-transformed for statistical analysis. Treatment means were back-transformed for reporting.

${ }^{\mathrm{y}}$ Data were square root-transformed for statistical analysis. Treatment means were back-transformed for reporting.

${ }^{\mathrm{x}}$ Means within each column and factor followed by the same letter are not significantly different at $\alpha=$ 0.05 . Columns without letters did not have significant analysis of variance treatment effects at $P \leq 0.05$. ${ }^{\mathrm{w}}$ Peatmoss occupied the remaining volume of each medium.

weight, and 2.6 times the number of root tips as cuttings in $50 \%$ perlite (Table 2; Fig. 3 ).

Field trial. All the plants in the landscape trial survived and grew in the garden site for the duration of the study. By the end of their spring growth flush in 2018, plants averaged $4(\mathrm{SD}=1)$ primary stems with an average caliper of $0.61 \mathrm{~cm}(\mathrm{SD}=0.21)$ and a height of $37.3 \mathrm{~cm}(\mathrm{SD}=9.3)$ from an initial height of $14.7 \mathrm{~cm}(\mathrm{SD}=3.1)$, with a canopy spread of
$39.8 \mathrm{~cm}(\mathrm{SD}=11.5)$. Seasonal stem elongation averaged $16.5 \mathrm{~cm}(\mathrm{SD}=4.1)$ in their first growing season in the field and $23.9 \mathrm{~cm}(\mathrm{SD}=$ 5.3 ) in the second growing season.

\section{Discussion}

Propagation success was high in both experiments, indicating that stem cuttings of mountain fly honeysuckle are suitable for 


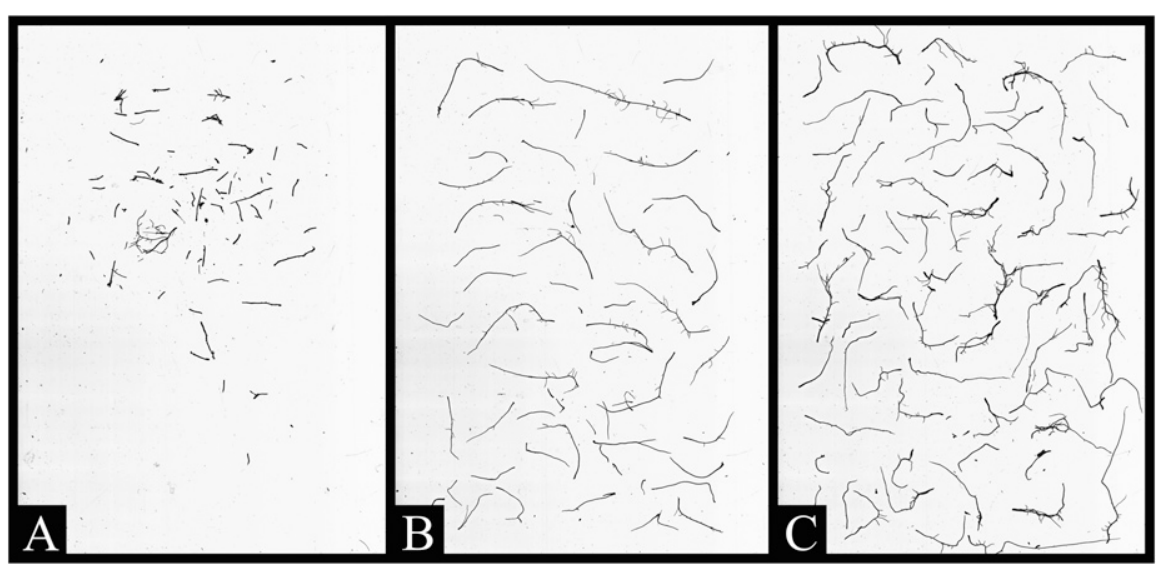

Fig. 3. Digital scans of the median root system (by dry weight) among cuttings propagated by subirrigation in each of three substrates: (A) $50 \%$ perlite and $50 \%$ peatmoss, (B) $75 \%$ perlite and $25 \%$ peatmoss, and (C) $100 \%$ perlite. Each digital scan represents an area of $21.5 \times 30 \mathrm{~cm}$.

propagation of clones for industry, research, or restoration purposes. Neither substrate composition nor K-IBA application significantly influenced the percentage of cuttings that produced roots. Subirrigation produced more variable rooting percentages than overhead mist, but no cuttings that produced roots in the subirrigation experiment subsequently died; mortality always occurred before the formation of adventitious roots. Survival in subirrigation, although acceptable, could be increased by simple methods to reduce transpiration from cuttings, such as the use of humidity domes or tents, without intermittent mist.

Auxin application significantly increased root volume, root dry weight, and number of root tips on cuttings in overhead mist, and root volume and number of root tips on cuttings in subirrigation (Table 2). The effect of auxin on these parameters was obvious, with a significant increase in root system quality between cuttings that received no auxin and cuttings that received K-IBA. Although there were few significant differences in adventitious root formation among the cuttings that received K-IBA, those treated with the greatest auxin concentration also showed no adverse effects of high auxin exposure (Tables 1 and 2). Therefore, we could not rule out the possibility that greater auxin concentrations, beyond the $12,000 \mathrm{mg} \cdot \mathrm{L}^{-1} \mathrm{~K}-\mathrm{IBA}$ that we tested, may yield cuttings more robustly rooted than those receiving lower concentrations. Regardless, the lower tested concentrations of 4000 to $8000 \mathrm{mg} \cdot \mathrm{L}^{-1} \mathrm{~K}-\mathrm{IBA}$ produced well-rooted plants, and concentrations even lower may be adequate for commercial propagation.

Although peatmoss is often added to rooting substrates to provide an organic component, cuttings of mountain fly honeysuckle produced the greatest measures of rooting in $100 \%$ perlite, and root system size diminished as peatmoss increased, regardless of system (Tables 1 and 2; Figs. 2 and 3). The superior root formation of cuttings in $100 \%$ perlite is comparable to results for some other woody species propagated by using overhead mist (AlSalem and Karam, 2001) or subirrigation (Coggeshall and Van Sambeek, 2001). Our experimental design precludes direct statistical comparison between the two propagation systems, but it is worth noting that cuttings in the subirrigation system produced more robust roots than those in the overhead mist system (Figs. 2 and 3). Unlike cuttings in overhead mist, many cuttings in the subirrigation system produced roots that escaped their cells and branched in the water trays by the date that cuttings in overhead mist were harvested. Others (Svenson, 2018; Zhang and Graves, 1995) have shown that subirrigation may outperform overhead mist for the propagation of some woody taxa. Although both systems are well suited to propagation of mountain fly honeysuckle, subirrigation in $100 \%$ perlite (Fig. 3) and auxin concentrations greater than $4000 \mathrm{mg} \cdot \mathrm{L}^{-1}$ permit the low-tech production of robustly rooted mountain fly honeysuckles when mist is not available.

Plants of mountain fly honeysuckle performed well with minimal care in a welldrained field soil low in organic matter. Plants maintained an attractive ratio of height-to-canopy spread, although with less dense foliage than observed in non-native ornamental honeysuckles, and stems at least 1 year old developed shaggy copper-colored bark that added to visual interest. The survival and growth of these rooted cuttings in the field trial indicates that mountain fly honeysuckle has sufficient adaptability for use in horticultural landscapes, despite its ecologic affinity for moist, organic habitats (Fernald, 1925). Of particular horticultural interest is our observation that the growth of plants in the landscape exceeded the scant growth typical of their counterparts indigenous to bogs and fens. When taken into consideration with ornamental characteristics, this suggests greater horticultural potential than might be evident by examining diminutive plants typically found in the wild.

\section{Literature Cited}

Al-Salem, M.M. and N.S. Karam. 2001. Auxin, wounding, and propagation medium affect rooting response of stem cuttings of Arbutus andrachne. HortScience 36:976-978.

Bailey, L.H. 1919. The standard cyclopedia of horticulture. Vol. 2. Macmillan, New York, NY.

Bouma, T.J., K.L. Nielsen, and B. Koutstaal. 2000. Sample preparation and scanning protocol for computerised analysis of root length and diameter. Plant Soil 218:185-196.

Coggeshall, M.V. and J.W. Van Sambeek. 2001. Development of a subirrigation system with potential for hardwood tree propagation. Proc. Intl. Plant Prop. Soc. 51:443-448.

de Mendiburu, F. 2016. agricolae: Statistical procedures for agricultural research. $\mathrm{R}$ package version 1.2-4. <https://CRAN.R-project.org/ package $=$ agricolae $>$.

Dirr, M.A. and C.W. Heuser, Jr. 2006. The reference manual of woody plant propagation. Timber Press, Portland, OR.

Dreesen, D., J. Harrington, T. Subirge, P. Stewart, and G. Fenchel. 2002. Riparian restoration in the Southwest: Species selection, propagation, planting methods, and case studies, p. 253-272. In: R.K. Dumrose, L.E. Riley, and T.D. Landis (eds.). Natl. Proc.: Forest and Conservation Nursery Assn., 1999, 2000, and 2001. Proc. RMRS-P-24. U.S. Dept. Agr. Forest Serv., Rocky Mountain Res. Sta., Ogden, UT.

Fernald, M.L. 1925. The American representatives of Lonicera caerulea. Rhodora 27:1-11.

Gerbrandt, E.M., R.H. Bors, R.N. Chibbar, and T.E. Baumann. 2017. Spring phenological adaptation of improved blue honeysuckle (Lonicera caerulea L.) germplasm to a temperate climate. Euphytica 213:172, doi: 10.1007/s10681-017-1958-5.

Hartmann, H.T., D.E. Kester, F.T. Davies, and R.L. Geneve. 2011. Hartmann and Kester's plant propagation: Principles and practices. 8th ed. Prentice Hall, Upper Saddle River, NJ.

Lesnoff, M. and R. Lancelot. 2012. aod: Analysis of overdispersed data. $\mathrm{R}$ package version 1.3. $<$ http://cran.r-project.org/package $=$ aod $>$.

Luken, J.O. and J.W. Thieret. 1996. Amur honeysuckle, its fall from grace. Bioscience 46:18 24.

Peterson, B.J., L.B. Stack, and D.J. Hayes. 2018. What do we know about the invasive potential of Lonicera caerulea L. cultivars in North America? Acta Hort. 1191:129-138.

R Core Team. 2016. R: A language and environment for statistical computing. R Foundation for Statistical Computing, Vienna, Austria. $<$ https://www.R-project.org/>.

Svenson, S.E. 2018. Rooting cuttings of Pieris species and hybrids in two propagation systems. Acta Hort. 1191:97-104.

U.S. Department of Agriculture Natural Resources Conservation Service. 2018a. The PLANTS database. National Plant Data Team, Greensboro, NC. 14 Feb. 2018. <http://plants. usda.gov>.

U.S. Department of Agriculture Natural Resources Conservation Service. 2018b. Web soil survey. 9 July 2018. <https://websoilsurvey.sc.egov. usda.gov/>.

Vittinghoff, E., D.V. Glidden, S.C. Shiboski, and C.E. McCulloch. 2011. Regression methods in biostatistics: Linear, logistic, survival, and repeated measures models. 2nd ed. Springer Science \& Business Media, New York.

Zhang, H. and W.R. Graves. 1995. Subirrigation to root stem cuttings: Comparison to intermittent mist and influence of fertilization. HortTechnology 5:265-268. 